\title{
A Proficiency-Based Comparative Investigation of Listening Comprehension Strategies Employed by Saudi EFL Learners
}

\author{
Choudhary Zahid Javid ${ }^{1}$ \\ ${ }^{1}$ Foreign Languages Department, Taif University, Taif, KSA \\ Correspondence: Dr. Choudhary Zahid Javid, Foreign Languages Department, Taif University, Al-Haweiyeh, Taif, \\ KSA. E-mail: chzahidj@hotmail.com
}

Received: October 5, 2018 Accepted: October 27, 2018 Online Published: November 6, 2018

doi:10.5539/ijel.v8n6p315 URL: https://doi.org/10.5539/ijel.v8n6p315

\begin{abstract}
The study in hand intends to investigate the comparative analyses of the perceptions of Saudi EFL learners with high grade point average (HGPA) and low-grade point average (LGPA) towards cognitive, metacognitive and socio-affective listening comprehension strategies employed by them to comprehend listening texts. A modified 5-point strongly agree to strongly disagree Likert-scale questionnaire has been administered to Saudi EFL learners with HGPA and LGPA to generate data for this empirical study. The reliability and validity of the questionnaire has been determined. The instrument was translated into Arabic which was administered to the cohort from both levels to identify their responses towards the various questionnaire items. Independent-samples T-test was run to determine descriptive statistics as well as to identify whether any statistically significant difference exist along GPA. The data generated through this comparative analysis were used to test three null hypotheses set for this study. The results have reported that by and large no significant differences exist in the perceptions of the HGPA and LGPA participants of this study and null hypotheses were accepted. It was found that Saudi EFL learners represented by the participants of this study resort to cognitive strategies the most followed by the metacognitive ones to comprehend listening texts. As far socio-affective strategies are concerned, the results indicate their least use by the participants of this study. The findings of this empirical study suggest that Saudi EFL learners like to exploit bottom-up strategies more than the top-down ones. Recommendations have been forwarded at the end based on the findings of this empirical study.
\end{abstract}

Keywords: cognitive, metacognitive, socio-affective, strategies, EFL learners, GPA

\section{Introduction}

English language teaching has a well-established history in Saudi Arabia and during the last two decades huge resources have been earmarked and serious efforts have been exerted to enhance English language teaching/learning process at all levels in general and at university level in particular to ensure the desired results. It has been reported that Saudi EFL learners bear serious lacking in the target language in general and oral skills in particular. (Javid, Farooq, \& Gulzar, 2012). The importance of oral skills is evident from the fact that during the process of actual communication, listening takes up 40-50\%; speaking $25-30 \%$; reading $11-16 \%$; and writing about $9 \%$ of the time of communication (Holden, 2004; Gilakjani \& Ahmadi, 2011). Many research studies have revealed that an increased interest has been witnessed in the role of strategy use in learning a language in general or in acquiring various language skills in particular (Javid \& Uthman, 2013; Eckerth, Schramm, \& Tschirner, 2009). The present study is an attempt to explore the use of listening comprehension strategies (LCS) by Saudi EFL learners along English proficiency level as determined by their GPA.

\subsection{Statement of the Problem}

Listening comprehension is reported to have been a problematic area for EFL learners and language learners usually consider it the most challenging skill to learn due to the complexity of its process (Graham \& Macaro, 2008). Graham (2006, p. 178) has stated that a vast majority of EFL "learners see themselves as less successful in listening than in other language areas" because of the factors like the speed of delivery of the target listening text and the accent of speaker. Goh (2000) has informed about these problems in terms of several barriers that negatively affect listening comprehension. According to him, these problems are caused by learners' low proficiency in the target language, their beliefs barriers, listening textbooks, information processing barriers, affective barriers, habitual berries along with lack of appropriate LCS. This situation calls for an identification of 
LCS employed by proficient language learners to compensate for the above-mentioned negative factors. It is argued that investigation of LCS used by successful language learners will provide a basis for learners with low English language proficiency to enhance their listening comprehension as well as English language proficiency. Therefore, the study in hand is an attempt to identify Saudi EFL leaners' LCS which will have positive pedagogical implications.

\subsection{Research Objective}

This empirical study aims to identify the following research objectives:

1) The comparative analyses of the responses of Saudi EFL students with high grade point average (HGPA) and low-grade point average (LGPA) towards the use of cognitive listening comprehension strategies

2) The comparative analyses of the responses of Saudi EFL students with HGPA and LGPA towards the use of metacognitive listening comprehension strategies

3) The comparative analyses of the responses of Saudi EFL students with HGPA and LGPA towards the use of socio-affective listening comprehension strategies

\subsection{Research Questions}

The following research questions have been set for this perceptive investigation:

1) Are there any statistically significant differences in the perceptions of Saudi EFL students with HGPA and LGPA towards the use of cognitive listening comprehension strategies?

2) Are there any statistically significant differences in the perceptions of Saudi EFL students with HGPA and LGPA towards the use of metacognitive listening comprehension strategies?

3) Are there any statistically significant differences in the perceptions of Saudi EFL students with HGPA and LGPA towards the use of socio-affective listening comprehension strategies?

\subsection{Null Hypotheses}

This study is meant to test the following null hypotheses:

1) There are no statistically significant differences in the perceptions of Saudi EFL students with HGPA and LGPA towards the use of cognitive listening comprehension strategies.

2) There are no statistically significant differences in the perceptions of Saudi EFL students with HGPA and LGPA towards the use of metacognitive listening comprehension strategies.

3) There are no statistically significant differences in the perceptions of Saudi EFL students with HGPA and LGPA towards the use of socio-affective listening comprehension strategies.

\section{Literature Review}

Research has emphasized the significance of LCS in acquiring a second/foreign language successfully (Rost, 2001; Vandergrift, 2007). Listening skills has been defined as "the ability of one individual perceiving another via sense, aural organs, assigning a meaning to the message and comprehending it" (p. 54). Contrary to the general assumption of considering listening comprehension as a passive activity, O'Malley, Chamot, \& Kupper (1989) have stated that "listening comprehension is an active and conscious process in which the listener constructs meaning by using cues from contextual information and from existing knowledge, while relying upon multiple strategic resources to fulfill the task requirement (p. 19)." Kassem (2015) has reported that efficient listeners effectively use LCS to comprehend the target listening texts better. He has further stated that LCS "if identified and described, can be taught to less successful learners to better their learning" and a growing mass of research of this type has developed "several, but similar taxonomies of listening strategies" (p. 156). Much research has been conducted to identify and classify LCS exploited by EFL/ESL learners (see for example Vandergrift, 2003; Liu, 2008; Serri, Boroujeni, \& Hesabi, 2012; Nowrouzi, Tam, Nimehchisalem, \& Zareian, 2014). Several other studies have investigated the comparative analyses of LCS used by more proficient and less proficient language learners (see for example Stæhr, 2008; Milton, Wade, \& Hopkins, 2010; Bidabadi \& Yamat, 2011; Tavakoli, Shahraki, \& Rezazadeh, 2012; Kassem, 2015). It has been reported that a growing mass of research has investigated the use of LCS in relation to variables like listening comprehension, self-efficacy and anxiety (Chen, 2007; Liu, 2008; Lu, \& Liu, 2011; Golchi, 2012; Ghapanchi, \& Golparvar, 2012). Several other studies have been quasi-experimental investigations which aimed at testing the role of LCS teaching on listening achievement in general as well as on various other relevant factors (Goh, 2006; Shang, 2008; Coşkun, 2010; Bidabadi, \& Yamat, 2011; Bozorgian \& Pillay, 2013; Rasouli, Mollakhan, \& Karbalaei, 2013 etc.). 
Piolat (2008) has informed that listening is usually considered a difficult skill as compared to other language skills as listeners have to simultaneously manage factors like speed of delivery, paucity of chances of the text repetition, limited vocabulary of listeners and lapses in concentration during extended listening texts. Research has also reported during the process of listening, learners need to comprehend and perceive the spoken texts "in order to make sense of it. The listener cannot refer back to the text in contrast to a reader who usually has the opportunity to refer back to clarify understanding" (Kurita, 2012, p. 30). Rubin (1994) has identified the following five factors that significantly affect learners' listening comprehension: They include:

1) the characteristics of the text such as speech rate, hesitation, level of perception, stress and rhythm of text, L1 and L2 differences, redundancy, the complexity of morpheme, the order of words, discourse markers, visual support, and modification of syntax;

2) the characteristics of speakers such as language proficiency and gender;

3) the characteristics of task such as task type;

4) the characteristics of listeners such as their memory, age, gender, attention, level of language proficiency, background knowledge, and learning disability in L1;

5) the characteristics of process such as "top-down, bottom-up, and parallel processing, listening strategies, and negotiation of comprehensible input" (pp. 197-198).

The above-mentioned factors make it rather difficult for ESL/EFL learners to master listening skills. Furthermore, it has also been reported that listening skills have been the least researched skills among all four language skills (Vandergrift, 2007).

Ghoneim (2013) has reported that LCS are the strategies which are used consciously or unconsciously by listeners to comprehend and interpret the target listening texts and an appropriate use of these strategies "can make authentic texts more accessible in the early stages of learning a language, so that the process becomes more relevant and interesting to the learners" (p. 101). He has further posited that LCS can be developed easily if learners are provided with frequent opportunities to have listening practice during their teaching sessions. Richards (2005) has informed that it is important for listening skills teachers to understand the difference between listening comprehension and listening acquisition as this bears significant pedagogical implications. Rost (2001) has stated that especially for adult learners "the processes of learning to listen (that is, learning to understand spoken messages) and listening to learn (that is, learning the syntax and lexis of the language through listening) do not coincide" (p. 97). Listening comprehension attempts to develop learners' skills in comprehending the target listening texts while listening acquisition focuses on enabling the listeners to pay close attention to the lexical and syntactic processes of the target language through listening. It has been revealed that the fundamental focus of the target listening development "is to allow for the L2 to be acquired through listening, not only to allow the learner to understand spoken messages in the L2" (Rost, 2001, p. 91). It has been reported that a growing mass of research has focused on understanding the LCS exploited by second/foreign learners to compensate for the difficulties they encounter during listening process by identifying listeners' mental processes and the facilitative strategies used by them (Thompson \& Robin, 1996; Vandergrift, 1999; Abdulhamid, 2012). Vandergrift (2007) has revealed that success of listeners mainly depends on using certain compensatory strategies like contextual, visual or paralinguistic information, knowledge of the world, relevant cultural information, use of common sense etc.

Krashen (1985) has stated that listening research prior to 1980s mainly based on the assumption that if listeners are merely exposed to extended comprehensible input, their listening comprehension would improve which would consequently promote chances of successful language acquisition. The later research studies have focused on the neglected aspect of listening input and emphasized on identifying the ways this input is manipulated by successful listeners. Abdulhamid (2012) has revealed that "understanding the strategies second language learners tend to use to cope with the difficulties they experience while listening had become an integral part of L2 listening research" (p. 14). It has also been posited that relevant research studies have mainly focused on understanding the mental processes of efficient listeners and identifying the facilitative strategies (Thompson \& Robin, 1996; Vandergrift, 1999).

The historical perspective informs us that the researchers who have investigated listening strategies initially have used language learning strategy taxonomies. It has been reported that the strategy model proposed by O'Malley \& Chamot (1990) has been exploited by majority of researchers. With the passage of time, the researchers have started using those models which have been specifically developed to investigate listening strategies (Vandergrift, 2003; Flowerdew \& Miller, 2005). Listening strategies have been categorized under metacognitive, cognitive and socio-affective strategies. 
Rubin (1987) has stated that metacognitive strategies involve management techniques which are exploited by the learners to manage their learning process through planning, monitoring, evaluating and modifying. Kassem (2015) has further clarified the various components of metacognitive strategies. He has stated that planning includes "advance organization, selective attention, self-management", and monitoring comprises of "comprehension monitoring and Double-check monitoring", whereas evaluating involves "self-assessment" (p. 115). Wenden (1998) has enumerated the following seven advantages who use metacognitive strategies. These advantages include 1) frequent use of learning strategies; 2) learning faster by integrating the stored knowledge; 3) defining themselves as constant receivers by effectively dealing with various situations; 4 ) having self-confidence to the extent of getting required help from peers, teachers and family members as needed; 5) the ability of observing and evaluating as prosperous learners; 6) the ability to handle unexpected situations throughout the listening task and 7) the ability to use strategies compatible to the listening task. Self-monitoring, selective attention and planning of cognitive strategies are various examples of Metacognition.

He has further elaborated that cognitive strategies are the ones which "listeners use to manipulate the material to be listened to by understanding the linguistic input". According to him these strategies comprise of identifying and exploiting relevant resources, arranging the collected information through grouping, linking it the previously acquired knowledge, doing proper note-taking, summarizing and seeking help through imagery, auditory representation and inferencing.

The review of relevant research has offered valuable insights that cognitive strategies bear a strong link with the target listening task and deals directly with the target material through manipulation and transformation (O'Malley \& Chamot, 1990). It is further elaborated that "language learners use cognitive strategies to help them process, store and recall new information (Goh, 1998, p. 124). It has been reported that bottom- up and top-down are the two main kinds of cognitive strategies which have been main focus of listening strategy research. Bottom-up strategies are the ones like word-for-word translation, managing listening speed, oral repetition of listening texts and concentrating on the prosodic features, whereas top-down strategies are higher level strategies including inferencing, predicting, elaborating and visualization. It has been reported that usually top-down strategies are exploited by advanced learners and bottom-up strategies are employed by beginners (O’Malley, Chamot, \& Kupper, 1989; Tsui \& Fullilove, 1998).

According to Vandergrift (2003), Socio-affective strategies are techniques which learners use to collaborate with their peers, to reinforce their understanding as well as to decrease anxiety. According to him, these strategies include the techniques of clarifying the questions, mutual cooperation and self-talk. Research has offered valuable insights into the fact that strategy use and listening proficiency are directly proportionate to each other and proficient listeners have been reported to use various listening strategies more frequently as compared to less proficient ones (Liu, 2008; Kassem, 2015). It has been revealed that efficient listeners effectively use metacognitive strategies such as exploiting more planning strategies, cognitive strategies including top-down processing and socio-affective strategies such as controlling their emotions (Kassem, 2015).

\section{Method}

\subsection{Research Design}

This empirical study investigated seventy-four ( $\mathrm{n}=74$ ) Saudi EFL students from a Saudi university to seek their perceptions towards the targeted cognitive, metacognitive and socio-affective listening comprehension strategies used by them to comprehend various listening texts by administering a 5-point Likert-scale questionnaire.

\subsection{Instrumentation}

Relevant studies have been consulted by the researcher to choose an appropriate instrument to record the perceptions of the participants of this survey report (See for example Vandergrift, 2003, 2007; Nowrouzi, Tam, Nimehchisalem, \& Zareian, 2014; Kassem, 2015). To elicit responses of the participants of this study, the researcher modified the questionnaire developed by Nowrouzi, Tam, Nimehchisalem, \& Zareian (2014) who have detailed complete procedure of development and validation of the instrument in their study. They have stated that the instrument was validated through item construction, expert feedback and pilot testing. The questionnaire had thirty-two $(n=32)$ items with a Likert-scale of always denoting 5 to never denoting 1 . The first twelve items $(n=12)$ were included to elicit reposes related to cognitive strategies, the next fifteen $(n=15)$ items meant to sought their participants' perceptions regarding metacognitive strategies whereas the last five items $(n=5)$ were related to socio-affective strategies. The final questionnaire had 35 items and the Cronbach's alpha remained as 0.87 for this instrument that in this study that indicates high level of reliability. 


\subsection{Research Ethics}

While talking about the research ethics, Graziano \& Raulin (2010) report that it is the duty of the researcher to inform the participants of their research about its purpose and scope. This knowledge about the scope of research will help the participants to decide whether they should like to participate in it or not. According to the considerations of the research ethics, the researcher handed a consent paper in advance which informed them about the scope and purpose of the study. It was also conveyed to them that the data collected through the questionnaire will only be used for the purpose of the present study and the participants would be anonymized. Graziano \& Raulin (2010) have stated that the anonymity of the participants of a study is used to protect their identities. As suggested by Vetenskapsrådet (1990), the researcher has also informed the participants that they could withdraw their participation in the study at any time and they would not face any negative consequences.

\subsection{Data Collection and Data Analyses}

The final translated version of the questionnaire, which has 32 items to elicit the participants' responses towards listening skills strategies, was generalized to the cohort of this empirical study. The researcher approached the participants during their teaching sessions, the purpose of the research was explained to them and they were requested to complete the survey. They were also briefed about the ethical issues as well and they were given 15 minutes to complete it. The data generated through the questionnaire were coded, manually entered in the version 20 of SPSS and Independent-samples T-test was run to calculate the descriptive statistics in terms of means as well as to determine whether any statistically significant difference exist in the perceptions of HGPA and LGPA groups. The data generated was tabulated to present the results of the present study and to discuss in relation to the relevant studies which have been conducted in various academic contexts in the following section.

\section{Results and Discussion}

Table 1. Comparative statistics for listening strategies

\begin{tabular}{llllll}
\hline No & Listening Strategies & Groups & Min & Max & Mean \\
\hline 1 & Cognitive strategies & HGPA & 3.191 & 4.617 & 3.945 \\
& & LGPA & 3.074 & 4.074 & 3.621 \\
2 & Metacognitive strategies & HGPA & 3.276 & 4.425 & 3.817 \\
& & LGPA & 3.407 & 4.185 & 3.693 \\
3 & Socio-affective strategies & HGPA & 2.766 & 4.361 & 3.663 \\
& & LGPA & 3.222 & 4.148 & 3.685 \\
\hline
\end{tabular}

Table above details the comparative mean values assigned by HGPA and LGPA groups to various cognitive, metacognitive and socio-affective strategies to increase their listening comprehension. The cumulative mean has indicated that HGPA group uses cognitive strategies the most followed by metacognitive whereas the socio-affective strategies are used the least confirming a growing mass of research in the Arab world as well as other parts of the world. Kassem (2015) has also reported that Egyptian EFL learners also use listening strategies as mentioned above. The same trend has been reported in several other studies which investigated Saudi, Iranian and French EFL learners respectively (See for example Al-Malki, 2018; Nowrouzi, Sim, Zareian, \& Nimehchisalem, 2014; Mohseny \& Raeisi, 2009; Vandergrift, 2003). Javid, Al-Thubaiti \& Uthman (2013) have investigated language learning strategies of 240 Saudi English major undergraduates and the results have indicated that learners with high English proficiency use these strategies more frequently as compared to low English proficiency group. It has also been revealed that have allocated highest preference to metacognitive strategies followed by Social, cognitive and affective language learning strategies respectively.

The results generated through the descriptive analyses of LGPA group have reported that they prefer the metacognitive strategies the most followed by socio-affective strategies and cognitive strategies remain at the bottom. Another interesting finding is that LGPA group has assigned higher cumulative mean to socio-affective strategies as compared to HGPA. Though majority of listening strategy studies conducted with EFL learners have reported the preference as reported by HGPA group but some other studies have also revealed metacognitive strategies as the most frequent among EFL learners followed by cognitive and socio-affective strategies (Bidabadi \& Yamat, 2011). The findings partially confirm the data generated by LGPA group. The results related to LGPA group are partially in line with findings of AbdulHamid (2012) who has stated that "advanced and intermediate ESL listeners use a great deal of socio-affective strategies". The findings have revealed valuable insights into the psychological underpinnings of Saudi EFL learners that Saudi EFL learners with HGPA prefer to exploit directly with the incoming information in terms of key words, contextual clues etc. to enhance their 
listening comprehension. On the other hand, Saudi EFL learners with LGPA try to compensate for their academic weakness by using techniques of planning, monitoring and seeking help from others to improve their listening comprehension.

Table 2. Independent samples t-test comparative statistics for cognitive strategies

\begin{tabular}{|c|c|c|c|c|c|c|c|c|c|}
\hline \multicolumn{2}{|c|}{ Questionnaire Items } & \multirow{2}{*}{$\begin{array}{l}\text { Group } \\
\text { HGPA }\end{array}$} & \multirow{2}{*}{$\begin{array}{ll}\mathrm{n} \\
47\end{array}$} & \multirow{2}{*}{$\begin{array}{ll}\mathrm{M} \\
4.148\end{array}$} & \multirow{2}{*}{$\begin{array}{ll}\text { SD } \\
.9995\end{array}$} & \multirow{2}{*}{$\begin{array}{l}\mathrm{T} \\
1.998\end{array}$} & \multirow{2}{*}{$\frac{\mathrm{df}}{72}$} & \multicolumn{2}{|c|}{$\mathrm{p}$ value } \\
\hline 1 & I use new words into a context to comprehend the & & & & & & & .050 & $\mathrm{p}>0.05$ \\
\hline & meaning. & LGPA & 27 & 3.666 & 1.000 & 1.997 & 54.299 & .051 & \\
\hline \multirow[t]{2}{*}{2} & I use guesses related to the topic depending on what & HGPA & 47 & 3.872 & .9235 & 1.717 & 72 & .090 & $\mathrm{p}>0.05$ \\
\hline & has already been said. & LGPA & 27 & 3.481 & .9754 & 1.692 & 51.892 & .097 & \\
\hline \multirow[t]{2}{*}{3} & I use the tone of voice to understand the word I hear. & HGPA & 47 & 4.191 & .8245 & 2.594 & 72 & .011 & $\mathrm{p}>0.05$ \\
\hline & & LGPA & 27 & 3.592 & 1.152 & 2.374 & 41.518 & .022 & \\
\hline \multirow[t]{2}{*}{4} & I use body language to understand the word I hear. & HGPA & 47 & 3.829 & 1.069 & 1.132 & 72 & .261 & $\mathrm{p}<0.05$ \\
\hline & & LGPA & 27 & 3.518 & 1.251 & 1.084 & 47.651 & .284 & \\
\hline \multirow[t]{2}{*}{5} & I use material in the answer sheet to understand the & HGPA & 47 & 3.766 & 1.164 & .783 & 72 & .436 & $\mathrm{p}>0.05$ \\
\hline & word I hear. & LGPA & 27 & 3.555 & 1.012 & .814 & 60.719 & .419 & \\
\hline \multirow[t]{2}{*}{6} & I practice sounds in the target language that are very & HGPA & 47 & 3.957 & .9990 & .422 & 72 & .674 & $\mathrm{p}<0.05$ \\
\hline & $\begin{array}{l}\text { different from sounds in my own language to become } \\
\text { comfortable with them. }\end{array}$ & LGPA & 27 & 3.851 & 1.099 & .411 & 50.154 & .683 & \\
\hline \multirow[t]{2}{*}{7} & I listen to the radio in the target language. & HGPA & 47 & 3.617 & 1.260 & -.560 & 72 & .577 & $\mathrm{p}<0.05$ \\
\hline & & LGPA & 27 & 3.777 & 1.050 & -.588 & 62.618 & .558 & \\
\hline \multirow[t]{2}{*}{8} & I watch English programs on TV. & HGPA & 47 & 4.404 & .9704 & 1.416 & 72 & .161 & $\mathrm{p}>0.05$ \\
\hline & & LGPA & 27 & 4.074 & .9578 & 1.421 & 54.913 & .161 & \\
\hline \multirow[t]{2}{*}{9} & I talk to foreigners in English. & HGPA & 47 & 4.446 & .8799 & 2.399 & 72 & .019 & $\mathrm{p}<0.05$ \\
\hline & & LGPA & 27 & 3.814 & 1.387 & 2.133 & 38.243 & .039 & \\
\hline \multirow[t]{2}{*}{10} & During listening, I make a written summary of the & HGPA & 47 & 3.191 & 1.154 & -.404 & 72 & .687 & $\mathrm{p}>0.05$ \\
\hline & main points. & LGPA & 27 & 3.296 & .9120 & -.431 & 64.828 & .668 & \\
\hline \multirow[t]{2}{*}{11} & I make a mental summary of information presented in a & HGPA & 47 & 3.510 & 1.120 & 1.639 & 72 & .106 & $\mathrm{p}>0.05$ \\
\hline & listening task. & LGPA & 27 & 3.074 & 1.071 & 1.659 & 56.352 & .103 & \\
\hline \multirow[t]{2}{*}{12} & I take notes of main points and keywords. & HGPA & 47 & 3.744 & 1.052 & 1.713 & 72 & .091 & $\mathrm{p}>0.05$ \\
\hline & & LGPA & 27 & 3.296 & 1.137 & 1.677 & 50.903 & .100 & \\
\hline \multirow[t]{2}{*}{13} & I watch movies in the target language. & HGPA & 47 & 4.617 & .9680 & 2.023 & 72 & .047 & $\mathrm{p}>0.05$ \\
\hline & & LGPA & 27 & 4.074 & 1.327 & 1.860 & 42.080 & .070 & \\
\hline
\end{tabular}

This table contains the comparative analyses of HGPA and LGPA responses towards cognitive strategies as generated by independent sample t-test. One major finding has been the trend of using cognitive strategies to increase their listening comprehension by HGPA group more frequently as compared to LGPA group. The data have revealed that HGPA group has assigned higher mean values to 11 items out of the total 13 items in this category. "Listening to radio" and "making a written summary of the main points" have been the items which were given higher mean by LGPA whereas all other cognitive strategies were allocated higher preferences by HGPA group.

Among the cognitive strategies, "watching movies in the target language" to increase their listening comprehension has been ranked at the top by both groups with an extremely high mean of 4.62 and 4.1 by HGPA and LGPA respectively. The findings are in line with several research studies conducted in the same academic context. Saudi medical undergraduates from college of medicine and medical sciences, Taif University have allocated high mean of 4.23 to the item which was meant to seek their perception regarding watching English movies to improve their target language skills (Javid, 2011). Likewise, Javid, Farooq, Gulzar \& Khan (2017) have also reported that Saudi EFL learners bear strong attitudes of watching English movies for their academic purposes. The second highest mean of 4.45 has been allocated by HGPA group to the item related to their preference to talk to foreigners in English. The results are in line with the findings of Javid, Farooq, Gulzar \& Khan (2017) who have also indicated that Saudi EFL learners also prefer to talk to native English language speakers to practice the target language. Comparatively low mean of 3.81 has been assigned to this item by LGPA group. The finding seems to suggest that Saudi EFL learners with higher English language proficiency use this technique to interacting with the foreigners to increase their exposure to the target language which consequently improves their listening comprehension. This technique does not seem to be favorite among Saudi EFL learners with low proficiency. The results partially confirm the findings reported by Javid (2014a) that Saudi university undergraduates do not feel anxious while talking to native English language speakers and they prefer to use this technique to get themselves acquainted with native accent. In line with the most favorite listening comprehension cognitive technique to 
watching English movies, both groups have assigned third highest mean of 4.404 and 4.07 to their preference to watch English programs on TV as well. Highest preferences to both these items seem to suggest that Saudi EFL learners understand the significance of continuous exposure to various accents of the target language to enable them to increase their listening comprehension. The questionnaire items which elicited the participants' responses towards using context clue method and exploiting the tone to guess the meaning of the target lexemes to improve their overall comprehension of the listening texts have also been allotted high mean values confirming the results of Javid, Al-Thubaiti \& Uthman (2013) and Javid (2011) that Saudi EFL learners prefer to use context clue method to guess the meaning of unknown words. Reasonably high mean has been reported by both groups to item stating that they practice sounds in the target language which are different from their mother tongue. Several research studies from the same academic context have also supported the finding of this empirical study. Javid, Al-Thubaiti \& Uthman (2013) have informed that Saudi English major students practice English sounds, repeat them and use English rhymes to get themselves familiar with the target sounds. Similarly finding is reported by Javid \& Uthman (2013) stating that Saudi EFL learners say English language sounds aloud and practice them by repeating again and again to improve their knowledge of English lexemes. Results related to all these items indicate quite an encouraging behavior among Saudi EFL learners as Liu (2002, p. 146) has posited that "limited exposure to varieties of spoken English is a major factor influencing learners' overall listening difficulties".

The least preferred items have been "making a written summary of the main points while listening" and "making a mental summary of information presented in a listening task". Both these items have been given low mean range of $3.00-3.5$ indicating that the participants of this study don't prefer using these strategies to comprehend listening tasks. The results are compatible with the findings of Javid, Al-Thubaiti \& Uthman (2013) who have stated that Saudi English major students also assigned low mean to the items which meant to elicit their perceptions about using summaries, taking notes and drawing mental pictures to help improve their various language skills. Similar findings have been forwarded by Javid \& Uthman (2013) indicating that Saudi EFL learners do not prefer to make pictures in their mind to memorize the target vocabulary. Similarly, the strategy of "taking notes of main points and keywords" has also been assigned medium lower mean.

Table 3. Independent samples t-test comparative statistics for metacognitive strategies

\begin{tabular}{|c|c|c|c|c|c|c|c|c|c|}
\hline \multicolumn{2}{|c|}{ Questionnaire Items } & \multirow{2}{*}{$\begin{array}{l}\text { Group } \\
\text { HGPA }\end{array}$} & \multirow{2}{*}{$\begin{array}{l}\mathrm{n} \\
47\end{array}$} & \multirow{2}{*}{$\begin{array}{l}\mathrm{M} \\
3.404\end{array}$} & \multirow{2}{*}{$\begin{array}{l}\text { SD } \\
.9245\end{array}$} & \multirow{2}{*}{$\begin{array}{l}\mathrm{T} \\
-.324\end{array}$} & \multirow{2}{*}{$\begin{array}{ll}\mathrm{df} \\
72\end{array}$} & \multicolumn{2}{|c|}{$\mathrm{p}$ value } \\
\hline 14 & I plan before listening. & & & & & & & .747 & $\mathrm{p}>0.05$ \\
\hline & & LGPA & 27 & 3.481 & 1.087 & -.310 & 47.454 & .758 & \\
\hline \multirow[t]{2}{*}{15} & \multirow{2}{*}{$\begin{array}{l}\text { I prepare for talks and performances I will hear in the } \\
\text { target language by reading some background } \\
\text { materials beforehand. }\end{array}$} & HGPA & 47 & 3.276 & 1.097 & -.814 & 72 & -.81 & $\mathrm{p}>0.05$ \\
\hline & & LGPA & 27 & 3.481 & .9352 & -.851 & 61.613 & -.85 & \\
\hline \multirow[t]{2}{*}{16} & \multirow{2}{*}{$\begin{array}{l}\text { I decide to focus on the topic and ignore the } \\
\text { distracters such as people and things around me. }\end{array}$} & HGPA & 47 & 4.000 & .9325 & .307 & 72 & .307 & $\mathrm{p}>0.05$ \\
\hline & & LGPA & 27 & 3.925 & 1.106 & .293 & 47.100 & .293 & \\
\hline \multirow[t]{2}{*}{17} & \multirow{2}{*}{$\begin{array}{l}\text { I attempt to listen for target details to check if I can } \\
\text { understand them. }\end{array}$} & HGPA & 47 & 4.170 & .8924 & 2.045 & 72 & 2.04 & $\mathrm{p}>0.05$ \\
\hline & & LGPA & 27 & 3.703 & 1.030 & 1.966 & 48.163 & 1.96 & \\
\hline \multirow[t]{2}{*}{18} & \multirow[t]{2}{*}{ I listen for key words. } & HGPA & 47 & 4.425 & .8006 & 1.133 & 72 & 1.13 & $\mathrm{p}<0.05$ \\
\hline & & LGPA & 27 & 4.185 & 1.001 & 1.067 & 45.160 & 1.06 & \\
\hline \multirow[t]{2}{*}{19} & \multirow{2}{*}{$\begin{array}{l}\text { I attempt to comprehend what I hear without doing } \\
\text { literal translation. }\end{array}$} & HGPA & 47 & 4.127 & .8996 & 1.657 & 72 & 1.65 & $\mathrm{p}<0.05$ \\
\hline & & LGPA & 27 & 3.703 & 1.295 & 1.505 & 40.642 & 1.50 & \\
\hline \multirow[t]{2}{*}{20} & \multirow{2}{*}{$\begin{array}{l}\text { I use my experience and knowledge to help me } \\
\text { comprehend. }\end{array}$} & HGPA & 47 & 4.340 & .9154 & 1.537 & 72 & 1.53 & $\mathrm{p}>0.05$ \\
\hline & & LGPA & 27 & 4.000 & .9198 & 1.535 & 54.105 & 1.53 & \\
\hline \multirow[t]{2}{*}{21} & \multirow[t]{2}{*}{ I try to keep up with the speed. } & HGPA & 47 & 3.787 & 1.020 & .038 & 72 & .038 & $\mathrm{p}<0.05$ \\
\hline & & LGPA & 27 & 3.777 & 1.012 & .039 & 54.650 & .039 & \\
\hline \multirow[t]{2}{*}{22} & \multirow{2}{*}{$\begin{array}{l}\text { I try to compare the developing interpretation with } \\
\text { my knowledge of the topic. }\end{array}$} & HGPA & 47 & 3.680 & 1.085 & .056 & 72 & .056 & $p>0.05$ \\
\hline & & LGPA & 27 & 3.666 & 1.000 & .057 & 58.077 & .057 & \\
\hline \multirow[t]{2}{*}{23} & \multirow{2}{*}{$\begin{array}{l}\text { I quickly adjust interpretation during listening if I } \\
\text { realize that it is not correct. }\end{array}$} & HGPA & 47 & 3.319 & .9349 & -.380 & 72 & -.38 & $\mathrm{p}<0.05$ \\
\hline & & LGPA & 27 & 3.407 & 1.009 & -.372 & 50.928 & -.37 & \\
\hline \multirow[t]{2}{*}{24} & \multirow{2}{*}{$\begin{array}{l}\text { I Think back to everything heard to verify the } \\
\text { meaningfulness of guessed words. }\end{array}$} & HGPA & 47 & 3.957 & 1.122 & .422 & 72 & .422 & $\mathrm{p}<0.05$ \\
\hline & & LGPA & 27 & 3.851 & .8639 & .453 & 65.851 & .453 & \\
\hline \multirow[t]{2}{*}{25} & As I listen, I sometimes ask myself if I am satisfied & HGPA & 47 & 3.893 & 1.047 & 1.672 & 72 & 1.67 & $\mathrm{p}>0.05$ \\
\hline & with my comprehension. & LGPA & 27 & 3.444 & 1.219 & 1.604 & 47.850 & 1.60 & \\
\hline 26 & After listening, I think back to how I listened and & HGPA & 47 & 3.936 & 1.030 & 1.182 & 72 & 1.18 & $\mathrm{p}<0.05$ \\
\hline & about what I might do differently next time. & LGPA & 27 & 3.629 & 1.148 & 1.147 & 49.595 & 1.14 & \\
\hline 27 & After listening, I recall the quality of my strategy use & HGPA & 47 & 3.723 & 1.210 & .750 & 72 & .750 & $\mathrm{p}>0.05$ \\
\hline & and about how I can do better next time. & LGPA & 27 & 3.518 & .9754 & .795 & 64.027 & .795 & \\
\hline 28 & I make a list of my problems and attempt to resolve & HGPA & 47 & 3.212 & 1.334 & -1.325 & 72 & -1.35 & $\mathrm{p}>0.05$ \\
\hline & them before my next Listening. & LGPA & 27 & 3.629 & 1.244 & -1.351 & 57.481 & -1.31 & \\
\hline
\end{tabular}


The perceptions of the participants of this empirical study were sought about 15 metacognitive strategies and a vast majority of the items have been assigned higher mean values by HGPA group indicating that effective use of metacognitive strategies increases listening comprehension. There have been only 4 items which showed higher preference by LGPA group. Furthermore, there is only one item which has exhibited significant difference in the perceptions of both groups indicating an extremely high unanimity of their perceived metacognitive strategies to improve their listening comprehension. Another significant finding is that there have been only 2 items which were allocated higher mean of more than 4 whereas all other items of this category have been assigned medium mean values.

The highest mean was recorded for the strategy of "listening to key words" to enhance their listening comprehension of the listening texts followed by using their "experience and knowledge" of the world to help improve listening comprehension. This attitude of Saudi EFL learners to concentrate on listening comprehension through key words and linking the reading texts to their personal experience instead of trying to understand each and every word seems quite pragmatic and promising and aligns with the findings of Javid, Al-Thubaiti \& Uthman (2013) who have informed that Saudi English major students prefer to read without looking up every new word. Item 23 has remained third most preferred item by HGPA group whereas LGPA group has allocated medium mean to this item. Their preference for these items has offered valuable insights into the fact that Saudi EFL learners understand that meaning of a listening text does not depend only on lexemes but they need to exploit their background knowledge and experiences as well as the contextual clues of the text to comprehend it properly. The overall findings of the study in hand confirm the findings of Abdelahmed (2012, p. 61) who has also reported that Arabic speaking ESL learners also prefer to use metacognitive strategies of "guessing the overall meaning of the text using the main idea or elaborating on new information using one's personal knowledge" to help them increase their listening comprehension skills".

Among the least preferred items, lowest mean has been reported for "reading some background material beforehand" to help improve their listening comprehension. The findings are in line with Javid \& Al-Khairi (2011) who have also reported that Saudi EFL learners do not have strong reading tradition. The second highest mean has been allocated to "preparing a list of problems to try to solve them before next listening". This also indicates that Saudi EFL learners do not prefer to indulge themselves in any systematic approach to enhance their listening comprehension partially confirming the findings of Javid, Al-Thubaiti \& Uthman (2013) who have revealed that Saudi English major students have assigned medium high mean values to analyze their mistakes and find out how to become better English language learners. The technique of "quickly adjusting interpretation while listening if I realize that it is not correct" has remained the third least preferred items. The result related to this item is also partially in line with findings of Javid (2014b). An interesting finding is that that all the least preferred items in this category have been assigned higher mean values by LGPA group as compared to their counterparts' mean values to nearly all other metacognitive strategies confirming the findings of Osada (2004) that learners with low English language proficiency usually use bottom-up strategies and try to exploit the information given in the target texts because they have difficulty in activating top-down strategies to understand the target texts.

Table 4. Independent samples t-test statistics for socio-affective strategies

\begin{tabular}{|c|c|c|c|c|c|c|c|c|c|}
\hline \multicolumn{2}{|c|}{ Questionnaire Items } & \multirow{2}{*}{$\begin{array}{l}\text { Group } \\
\text { HGPA }\end{array}$} & \multirow{2}{*}{$\begin{array}{l}\mathrm{n} \\
47\end{array}$} & \multirow{2}{*}{$\begin{array}{l}\text { M } \\
3.212\end{array}$} & \multirow{2}{*}{$\begin{array}{l}\text { SD } \\
1.458\end{array}$} & \multirow{2}{*}{$\begin{array}{l}\mathrm{T} \\
-.353\end{array}$} & \multirow{2}{*}{$\begin{array}{l}\mathrm{df} \\
72\end{array}$} & \multicolumn{2}{|c|}{$\mathrm{p}$ value } \\
\hline 29 & I seek others' feedback to solve my listening problems. & & & & & & & .725 & $\mathrm{p}>0.05$ \\
\hline & & LGPA & 27 & 3.333 & 1.330 & -.362 & 58.541 & .718 & \\
\hline \multirow[t]{2}{*}{30} & I participate out-of-class programs where the new & HGPA & 47 & 2.766 & 1.322 & -1.57 & 72 & .119 & $\mathrm{p}>0.05$ \\
\hline & language is spoken. & LGPA & 27 & 3.222 & .9337 & -1.73 & 68.802 & .088 & \\
\hline \multirow[t]{2}{*}{31} & I imitate the way native speakers talk. & HGPA & 47 & 3.957 & 1.141 & -.602 & 72 & .549 & $\mathrm{p}>0.05$ \\
\hline & & LGPA & 27 & 4.111 & .8915 & -.643 & 65.289 & .523 & \\
\hline \multirow[t]{2}{*}{32} & I force myself to listen more even when I am afraid of & HGPA & 47 & 4.191 & 1.096 & 2.086 & 72 & .041 & $\mathrm{p}<0.05$ \\
\hline & issues in comprehension. & LGPA & 27 & 3.629 & 1.148 & 2.060 & 52.246 & .044 & \\
\hline \multirow[t]{2}{*}{33} & I give myself a reward or treat when I improve in & HGPA & 47 & 3.489 & 1.396 & -.673 & 72 & .503 & $\mathrm{p}>0.05$ \\
\hline & listening. & LGPA & 27 & 3.703 & 1.170 & -.706 & 62.348 & .483 & \\
\hline \multirow[t]{2}{*}{34} & I hope teachers can teach me more skills to improve my & HGPA & 47 & 4.361 & 1.111 & .765 & 72 & .447 & $\mathrm{p}>0.05$ \\
\hline & listening comprehension. & LGPA & 27 & 4.148 & 1.231 & .744 & 49.877 & .460 & \\
\hline
\end{tabular}


The table above contains the data analyses related to 6 socio-affective strategies indicating only 1 item with statistically significant difference highlighting that both groups saw eye to eye to each other in their perceptions. The results also revealed that the LGPA group has assigned higher mean values to 4 out of the total 6 items of this category contrary to cognitive and metacognitive strategies where higher mean has been assigned to the majority items by HGPA group. It is also important that usually socio-affective strategies are not taught to EFL learners whereas cognitive and metacognitive listening strategies are part of routine listening strategies pedagogy. Riazi (2007) has emphasized the important role of the instructors in encouraging the use of social and affective strategies as compared to the other types of strategies so that they may be able to benefit from each other as well to enhance their listening strategies.

Both groups have unanimously assigned the highest mean to the item stating that they "hope teachers can teach them more skills to improve their listening comprehension" confirming much research conducted in the KSA indicating that Saudi EFL learners want expert teachers who provide them with ready-made answers (Javid, 2014a). It is also in line with Javid, Farooq, Gulzar \& Khan (2017) that Saudi EFL learners bear strong attitude of getting immediate feedback from their teachers instead of trying themselves to reach at the correct answers. Similar findings have been reported by Javid (2011) who has investigated Saudi medical undergraduates' learning styles. The next two highest ranking items have been "I encourage myself to listen more even when I am afraid of problems in understanding" and "I imitate the way native speakers talk" respectively. Both these items seem to suggest that Saudi EFL learners bear positive attitude of persistence in listening practice even though they face some problems and their preference to have exposure of native accents to help improve their listening skills. The result of the second most preferred item in this category is in line with Javid, Al-thubaiti \& Uthman (2013) who have found out that Saudi university undergraduates prefer to keep on speaking the target language even if they make mistakes. Medium high preference has been shown for the items related to "seeking others' feedback on how to solve listening problems" and "rewarding oneself after exhibiting improvement in listening". Much research has offered insights into the fact that Saudi EFL learners' bear medium high preference for seeking help from their peers (Javid, Al-thubaiti \& Uthman, 2013; Javid, 2011). Javid, Al-thubaiti \& Uthman (2013) have also reported that Saudi university undergraduates reward themselves when they perform better in some language skill.

The least preferred items have been their efforts to "attend out-of-class events like conferences" and "asking their peers for feedback on how to solve their listening problems". Their lack of preference for activities like conferences etc. seems logical as usually EFL learners do not consider them instrumental in enhancing their language skills and they do not participate frequently in these academic events. Their hesitation to seek their peers' help is in line with the previous research in the same academic echo system that has reported that Saudi university undergraduates do not want their peers to know their mistakes and weaknesses and prefer to seek academic help only from their teachers (Javid, 2011; Javid, Al-thubaiti \& Uthman, 2013).

\section{Conclusion and Recommendations}

The comparative analyses of the perceptions of HGPA and LGPA groups about cognitive, metacognitive and socio-affective listening strategies reveal that in general the students with high GPA tend to use more strategies as compared to the ones with low GPA. The findings indicate that HGPA group uses cognitive strategies the most followed by metacognitive and socio-affective respectively whereas the LGPA cohort of this empirical study uses metacognitive strategies the most followed by socio-affective. The cognitive strategies have been reported to be used least by this LGPA group. The findings seem to suggest that Saudi EFL learners represented by the participants of this study prefer to exploit bottom-up strategies more as compared to the top-down ones. Much research has offered valuable insights into the fact that listening comprehension is a difficult and challenging area for EFL learners because listening involves complex processing of learners' background knowledge along with relevant linguistics skills. Furthermore, what makes the task rather more difficult is the speed of delivery where the listeners have no control. The following are the recommendations presented based on the findings of this empirical study. It seems important that English language teachers should work with their students to identify their listening strategies and help them strengthen the strategies which improve their listening comprehension. It is recommended that once the students understand the listening process and realize the significance of using listening strategies, they will be motivated to use them more and their listening comprehension will increase. Another major problem is that usually EFL students resort to traditional strategies of looking up each and every word from the dictionaries to enhance their listening text understanding (Farshid, 2003) instead of trying to exploit LCS. There is a need to make the students understand and execute appropriate strategies to improve their listening comprehension. Vandergrift (1997) has emphasized that training students to use LCS more frequently is the most effective way to enhance their listening comprehension. Therefore, it seems mandatory that EFL students should know what these strategies are and how these strategies can be exploited effectively. It is also important that English language faculty should 
seriously consider effective methods such as interactive model of teaching listening comprehension proposed by Brown (2001) which includes teaching of bottom-up and top-down processing skills to improve their students listening comprehension. In this regard a growing mass of instructional material in available that is instrumental in teaching these processing strategies (Brown, 2001; Rost, 2002; Ur, 1984). An important finding of this empirical study is comparatively lower use of socio-affective strategies particularly by HGPA group which calls for incorporation of teaching these strategies in listening skills courses. These strategies will help EFL learners to overcome the affective problems namely low self-esteem issues, high level of anxiety and nervousness, motivation issues and embarrassment which cause learners' affective performance (Gebra, 2015). It is also recommended that further research is needed to investigate insufficient use of socio-affective listening comprehension strategies as suggested by the findings of this study as well as several other studies in the similar context. It is also recommended that a wider scale investigation should be carried out to investigate the use of LCS as this study involves comparatively smaller number of participants.

\section{References}

Abdalhamid, F. (2012). Listening comprehension strategies of Arabic-speaking ESL learners. MA thesis submitted to Colorodo State University, Fort Collins, Colorado.

Al-Malki, E. A. (2018). A Perceptive Determination of Self-perceived Listening Comprehension Strategies Employed by Saudi English-major University Undergraduates. Arab World English Journal, 9(1), 281-293. https://doi.org/10.24093/awej/vol9no1.20

Bidabadi, F., \& Yamat, H. (2011). The relationship between listening strategies used by Iranian EFL freshman university students and their listening proficiency levels. English Language Teaching, 4(1), 26-32. https://doi.org/10.5539/elt.v4n1p26

Bozorgian, H., \& Pillay, H. (2013). Enhancing Foreign Language Learning through Listening Strategies Delivered in L1: An Experimental Study. International Journal of Instruction, 6(1), 105-122.

Brown, H. (2001). Teaching by principles: An interactive approach to language pedagogy (2nd ed.). New York: Longman.

Chen, H. (2007). The Relationship between EFL Learners' Self-Efficacy Beliefs and English Performance. Retrieved from http://diginole.lib.fsu.edu/etd/3846/

Coşkun, A. (2010). The effect of metacognitive strategy training on the listening performance of beginner students. Novitas-ROYAL, 4(1), 35-50.

Cross, J. (2009). Effects of listening strategy instruction on news videotext comprehension. Language Teaching Research, 13, 151-176. https://doi.org/10.1177/1362168809103446

Eckerth, J., Schramm, K., \& Tschirner, E. (2009). Review of recent research (2002-2008) on applied linguistics and language teaching with specific reference to L2 German (part 1). Language Teaching, 42(1), 41-66. https://doi.org/10.1017/S0261444808005405

Farshid, M. (2003). The effects of separate and integrated presentation of reading strategies on the reading comprehension ability of the Iranian students. MA Thesis, Allameh Tabatabaie University, Iran.

Flowerdew, J. H., \& Miller, L. (2005). Second language listening: Theory and practice. New York: Cambridge University Press. https://doi.org/10.1017/CBO9780511667244

Gebre, B. M. (2015). The Role of Listening Strategy Instruction in Advancing Students' Listening Achievement and Strategy Use. International Journal of Foreign Language Teaching \& Research, 3(11), 15-24.

Ghapanchi, Z., \& Golparvar, S. (2012). Foreign language listening anxiety in Iranian EFL context. International Journal of Social Sciences and Humanities, 1, 16-22.

Ghoneim, N. M. M. (2013). The Listening Comprehension Strategies Used by College Students to Cope with the Aural Problems in EFL Classes: An Analytical Study. English Language Teaching, 6(2), 100-112.

Gilakjani, A. P., \& Ahmadi, M. R. (2011). A Study of Factors Affecting EFL Learners' English Listening Comprehension and the Strategies for Improvement. Journal of Language Teaching and Research, 2(5), 977-988. https://doi.org/10.4304/jltr.2.5.977-988

Goh, C. (1998). How ESL learners with different listening abilities use comprehension strategies and tactics. Language Teaching Research, 2, 124-147. https://doi.org/10.1177/136216889800200203 
Goh, C. (2000). A cognitive perspective on language learners' listening comprehension problems, Systems, 28 , 55-75. https://doi.org/10.1016/S0346-251X(99)00060-3

Goh, C. (2006). Metacognitive instruction in listening for young learners. ELT Journal, 60, 222-232. https://doi.org/10.1093/elt/ccl002

Golchi, M. (2012). Listening anxiety and its relationship with listening strategy use and listening comprehension among Iranian IELTS learners. International Journal of English Linguistics, 2(4), 115-128.

Graham, S. (2006). Listening comprehension: The learners' perspective. System, 34(2), 165-182. https://doi.org/10.1016/j.system.2005.11.001

Graham, S., \& Macaro, E. (2008). Strategy instruction in listening for lower intermediate learners of French. Language Learning, 58, 747-778. https://doi.org/10.1111/j.1467-9922.2008.00478.x

Graziano, A. M., \& Raulin, M. (2010). Research Methods: a Process of Inquiry. Boston: Pearson.

Holden, W. R. (2004). Facilitating Listening Comprehension: Acquiring Successful Strategies. Bulletin of Hokuriku University, 28, 257-266.

Javid, C. Z. (2011). Saudi medical undergraduates' perceptions of their preferred learning styles and evaluation techniques. Arab World English Journal, 2(2), 40-70.

Javid, S. Z. (2014a). Measuring Language Anxiety in an EFL Context. Journal of Education and Practice, 5(25), pp. 180-193. Available online http://www.iiste.org/Journals/index.php/JEP/article/view/15295

Javid, C. Z. (2014b). A Comparative Determination of Vocabulary Learning Strategies of Saudi EFL Learners. Research Journal of Recent Sciences, 3(12), 32-41.

Javid, C. Z., \& Khairi, M. H. (2011). The role of pleasure reading in enhancing reading speed and reading comprehension. Arab World English Journal, 2(4), 219-256.

Javid, C. Z., \& Uthman, A. A. (2013). An Analysis of Saudi English-major Undergraduates' self reported beliefs about Vocabulary Learning Strategies: A comparative Study. Pensee Journal, 75(12), 279-293.

Javid, C. Z., Al-thubaiti, T. S., \& Uthman, A. (2013). Effects of English Language Proficiency on the Choice of Language Learning Strategies by Saudi English-major Undergraduates. English Language Teaching, 6(1), $35-47$.

Javid, C. Z., Farooq, U., \& Gulzar, M. A. (2012). Saudi English-major undergraduates and English Teachers' perceptions regarding effective ELT in the KSA: A Comparative Study. European Journal of Scientific Research, 85(1), 55-70.

Javid, C. Z., Farooq, U., Gulzar, M. A., \& Khan, M. (2017). Attitudes of EFL learners towards English Language Teaching. NUML Journal of Critical Inquiry, 15(1), 44-66.

Kassem, H. M. (2015). The Relationship between Listening Strategies Used by Egyptian EFL College Sophomores and Their Listening Comprehension and Self-Efficacy. English Language Teaching, 8(2), 153-169. https://doi.org/10.5539/elt.v8n2p153

Krashen, S. D. (1985). The input Hypothesis: Issue and Implications. London: Longman.

Kurita, T. (2012). Issues in second language listening comprehension and the pedagogical implications. Accents Asia, 5(1), 30-44.

Liu, H. (2008). A study of the interrelationship between listening strategy use, listening proficiency levels, and learning style. ARECLS, 5, 84-104.

Liu, N. F. (2002). Processing problems in L2 listening comprehension of university students in Hong Kong (Doctoral dissertation). Retrieved from ProQuest Dissertations \& Theses database.

Lu, Z., \& Liu, M. (2011). Foreign language anxiety and strategy use: A study with Chinese undergraduate EFL learners. Journal of Language Teaching and Research, 2, 1298-1305. https://doi.org/10.4304/jltr.2.6.1298-1305

Milton, J., Wade, J., \& Hopkins, N. (2010). Aural word recognition and oral competence in a foreign language. In R. C. Beltrán, C. Abello-Contesse, \& M. del Mar Torreblanca-López (Eds.), Insights into non-native vocabulary teaching and learning (pp.83-98). UK: Multilingual Matters.

Mohseny, A., \& Raeisi, N. (2009). The Relationship between Language Proficiency of EFL Students and Their Strategy Use in Listening Comprehension. TEFLL, 1(4), 111-132. 
Nowrouzi, S., Sim, T. S., Zareian, G., \& Nimehchisalem, V. (2014). Self-perceived Listening Comprehension Strategies Used by Iranian EFL Students. International Journal of Applied Linguistics \& English Literature, $3(6), 35-41$.

Nowrouzi, S., Tam, S. S., Nimehchisalem, V., \& Zareian, G. (2014). Developing an instrument for Iranian EFL learners' listening comprehension problems and listening strategies. Advances in Language and Literacy Studies 5(3).

O’Malley, J. M., \& Chamot, A. U. (1990). Learning strategies in second language acquisition. Cambridge: Cambridge University Press. https://doi.org/10.1017/CBO9781139524490

O’Malley, J., Chamot, A., \& Kupper, L. (1989). Listening comprehension strategies in second language acquisition. Applied Linguistics, 10, 418-437. https://doi.org/10.1093/applin/10.4.418

Osada, N. (2004). Listening Comprehension Research: A Brief Review of the Past Thirty Years. Dialogue, 3, 53-66.

Piolat, A. (2008). Fluency and Cognitive Effort During First- and Second-Language Notetaking and Writing by Undergraduate Students. European Psychologist. 13(2). https://doi.org/10.1027/1016-9040.13.2.114

Rasouli, M., Mollakhan, K., \& Karbalaei, A. (2013). The effect of metacognitive listening strategy training on listening comprehension in Iranian EFL context. European Online Journal of Natural and Social Sciences, 2(1), 115-128.

Richards, J. C. (2005). Second thoughts on teaching listening. RELC Journal, 36, 85-92. https://doi.org/10.1177/0033688205053484

Rost, M. (2001). Teaching and researching listening. London: Longman.

Rost, M. (2002). Teaching and Researching Listening. London, UK: Longman.

Rubin, J. (1987). Learner strategies: Theoretical assumptions, research history and typology. In L. Wenden \& J. Rubin (Eds.), Learner strategies in language learning (pp. 15-30). Englewood Cliffs, NJ: Prentice-Hal.

Rubin, J. (1994). A Review of Second Language Listening Comprehension Research. The Modern Language Journal, 78(2), 199-221. https://doi.org/10.1111/j.1540-4781.1994.tb02034.x

Serri, F., Boroujeni, A., \& Hesabi, A. (2012). Cognitive, Metacognitive, and Social/Affective Strategies in Listening Comprehension and Their Relationships with Individual Differences. Theory and Practice in Language Studies, 2(4), 843-849. https://doi.org/10.4304/tpls.2.4.843-849

Shang, H. (2008). Listening Strategy Use and Linguistic Patterns in Listening Comprehension by EFL Learners. The Intl. Journal of Listening, 22(1), 29-45. https://doi.org/10.1080/10904010701802147

Stæhr, L. S. (2008). Vocabulary size and the skills of listening, reading and writing. Language Learning Journal, 36(2), 139-152. https://doi.org/10.1080/09571730802389975

Tavakoli, M., Shahraki, S., \& Rezazadeh, M. (2012). The relationship between metacognitive awareness and EFL listening performance: focusing on IELTS higher and lower scorers. The Journal of Language Teaching and Learning, 2, 24-37.

Thompson, I., \& Rubin, J. (1996). Can strategy instruction improve listening comprehension? Foreign Language Annals, 29, 331-342. https://doi.org/10.1111/j.1944-9720.1996.tb01246.x

Tsui, A., \& Fullilove, J. (1998). Bottom-up or top-down processing as a discriminator of L2 listening performance. Applied Linguistics, 19, 432-451. https://doi.org/10.1093/applin/19.4.432

Ur, P. (1984). Teaching listening comprehension. Cambridge: Cambridge University Press.

Vandergrift, L. (1997). The strategies of second language (French) listeners. Foreign Language Annals, 30, 387-409. https://doi.org/10.1111/j.1944-9720.1997.tb02362.x

Vandergrift, L. (1999). Facilitating second language listening comprehension: Acquiring successful strategies. ELT Journal, 53, 168-173. https://doi.org/10.1093/elt/53.3.168

Vandergrift, L. (2003). Orchestrating strategy use: Toward a model of the skilled second language listener. Language Learning, 53(3), 463-496. https://doi.org/10.1111/1467-9922.00232

Vandergrift, L. (2007). Recent developments in second and foreign language listening comprehension research. Language Teaching, 40, 191-210. https://doi.org/10.1017/S0261444807004338 
Vetenskapsrådet. (1990). Forskningsetiska principer inom humanistisk-samhällvetenskaplig forskning. Retrieved from http://www.codex.vr.se/texts/HSFR.pdf

Wenden, A. (1998). Metacognitive knowledge and language learning. Applied Linguistics, 19(4), $515-537$. https://doi.org/10.1093/applin/19.4.515

\section{Copyrights}

Copyright for this article is retained by the author, with first publication rights granted to the journal.

This is an open-access article distributed under the terms and conditions of the Creative Commons Attribution license (http://creativecommons.org/licenses/by/4.0/). 